\title{
Current overview and treatment of mantle cell lymphoma
}

\section{[version 1; peer review: 3 approved]}

\author{
Michael Schieber(D, Leo I. Gordon, Reem Karmali
}

Robert H. Lurie Comprehensive Cancer Center of Northwestern University, Chicago, Illinois, USA

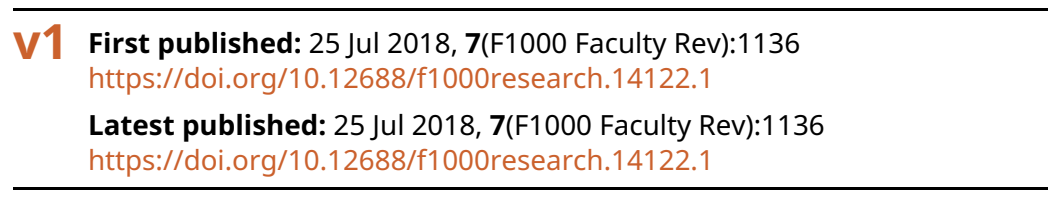

\section{Abstract}

Mantle cell lymphoma (MCL) is a B-cell non-Hodgkin lymphoma with historically poor long-term survival compared with other B-cell malignancies. Treatment strategies for this disease are variable and dependent on symptoms and patient fitness. Despite recent advances, $M C L$ remains incurable and patients with high-risk disease have particularly poor outcomes. This review focuses on recent developments that enhance our understanding of the biology of $\mathrm{MCL}$ and new treatment approaches that have led to substantial improvements in clinical outcomes. We will outline induction immunochemotherapy and maintenance strategies in transplant-eligible patients. In addition, effective strategies for patients unfit for intensive induction will be discussed, with a particular focus on novel molecular therapies with activity in MCL. Lastly, a number of ongoing clinical trials will be presented; the data from these trials are anticipated to redefine standards of care in the near future.

\section{Keywords}

Mantle Cell Lymphoma, Management, Treatment, Diagnosis, Clinical trials

\section{Open Peer Review \\ Approval Status \\ 12 \\ 23 \\ version 1 \\ 25 Jul 2018 \\ Faculty Reviews are review articles written by the prestigious Members of Faculty Opinions. The articles are commissioned and peer reviewed before publication to ensure that the final, published version is comprehensive and accessible. The reviewers who approved the final version are listed with their names and affiliations. \\ 1. Vincent Ribrag, Gustave Roussy Comprehensive Cancer Center, Villejuif, France}

2. Jonathon B. Cohen, Emory University, Atlanta, USA

3. Andre H. Goy, John Theurer Cancer Center, Hackensack, USA

Any comments on the article can be found at the end of the article. 
Corresponding authors: Leo I. Gordon (l-gordon@northwestern.edu), Reem Karmali (reem.karmali@northwestern.edu)

Author roles: Schieber M: Writing - Original Draft Preparation, Writing - Review \& Editing; Gordon LI: Writing - Review \& Editing; Karmali R: Writing - Original Draft Preparation, Writing - Review \& Editing

Competing interests: No competing interests were disclosed.

Grant information: The author(s) declared that no grants were involved in supporting this work.

Copyright: (c) 2018 Schieber $\mathrm{M}$ et al. This is an open access article distributed under the terms of the Creative Commons Attribution License, which permits unrestricted use, distribution, and reproduction in any medium, provided the original work is properly cited.

How to cite this article: Schieber M, Gordon LI and Karmali R. Current overview and treatment of mantle cell lymphoma [version 1; peer review: 3 approved] F1000Research 2018, 7(F1000 Faculty Rev):1136 https://doi.org/10.12688/f1000research.14122.1

First published: 25 Jul 2018, 7(F1000 Faculty Rev):1136 https://doi.org/10.12688/f1000research.14122.1 


\section{Introduction}

Mantle cell lymphoma (MCL) is an aggressive mature B-cell non-Hodgkin lymphoma (B-NHL) with historically poor long-term survival. Recent progress in our understanding of the biology of MCL has led to substantial improvements in patient outcomes and the development of a number of novel targeted therapies. In this review, the pathogenesis of MCL will be reviewed with a focus on newly defined MCL subtypes that predict response to therapy. We will discuss the major breakthroughs in MCL care in the past 5 years, including recent phase III clinical data that reinforce the use of high-dose cytarabine induction immunochemotherapy in fit patients. There are now data from randomized studies supporting the use of rituximab maintenance in MCL post-autologous stem cell transplant (ASCT). A number of new strategies for the management of patients unfit for ASCT will be reviewed. For those patients who unfortunately experience a relapse of their disease, a number of novel therapies have demonstrated substantial benefit, most notably the Bruton's tyrosine kinase (BTK) inhibitors ibrutinib and acalabrutinib. Lastly, mechanisms of therapy resistance as well as future directions of treatment will be discussed.

\section{Biology of mantle cell lymphoma}

While defined as a mature B-NHL, MCL has a clinical presentation and natural course that often mimic its more aggressive B-NHL counterparts. Patients commonly have lymphadenopathy, splenomegaly, bone marrow involvement, and gastrointestinal infiltration at the time of diagnosis. MCL is classically defined by the $\mathrm{t}(11 ; 14)(\mathrm{q} 13 ; \mathrm{q} 32)$ translocation which juxtaposes the CCDN1 gene encoding cyclin D1 to the immunoglobulin heavy chain $(\operatorname{IgH})$, resulting in the overexpression of cyclin D1. Alternatively, less-frequent alterations in $C C N D 2$ and $C C N D 3$, encoding cyclin D2 and D3, respectively, have been identified in MCL lacking the $\mathrm{t}(11 ; 14)(\mathrm{q} 13 ; \mathrm{q} 32)$ translocation ${ }^{1}$. However, over the past decade, further investigation into the pathogenesis of MCL has defined other molecular abnormalities that define cyclin D1-negative MCL.

SOX11, a SOX family transcription factor with a role in cell fate and differentiation, has been identified as a reliable diagnostic and prognostic marker of MCL in both cyclin D1-positive and -negative disease $^{2}$. Microarray analyses and protein expression quantification by immunohistochemistry (IHC) have shown that SOX11 overexpression is an independent molecular feature of MCL regardless of cyclin D1 status. Furthermore, a complex transcription signature accompanies the overexpression of SOX11. This includes the regulation of the transcription factor PAX5, which is critical for late B-cell differentiation ${ }^{3}$. Increased PAX5 levels repress the key transcriptional regulators of plasma cell differentiation BLIMP1, XB1, and IRF4. Supporting this, increased SOX11 expression correlates with an unmutated or minimally mutated $I G H V$ genotype, a marker of germinal center maturation and differentiation into memory B-cells ${ }^{4}$. Loss of SOX11 expression, and subsequent downregulation of PAX5, correlates with a hypermutated $I G H V$ genotype, reflective of early steps towards plasma cell differentiation. Clinically, low SOX11 expression correlates with a more indolent and non-nodal leukemic phase presentation, whereas increased SOX11 expression portends a more aggressive phenotype with nodal and extra-nodal sites of involvement. Taken together, the implementation of CCND2, $C C N D 3$, SOX11, and $I G H V$ analysis has expanded criteria for the molecular diagnosis of MCL.

\section{Prognostic variables and observation in mantle cell lymphoma}

MCL is thought to be an aggressive disease in most patients, associated with early relapse and poor long-term survival. Standard of care strategies continue to emphasize aggressive treatment approaches, which have demonstrated the longest durable remissions. However, observation can be considered in patients with favorable disease features ${ }^{5,6}$. Easily obtained clinical variables provide excellent risk stratification of patients. The MCL International Prognostic Index (MIPI) incorporates patient age, performance status, lactate dehydrogenase (LDH), and white blood cell count into a formula to stratify patients as low, intermediate, or high risk; 5-year overall survival for MIPI-low patients was $83 \%$ compared with $34 \%$ in MIPI-high patients, with a high MIPI score also predicting inferior response to therapy ${ }^{7}$. A similar tool, the Biologic MIPI, incorporates the Ki-67 proliferation rate, usually readily obtained from pathology specimens, to better identify high-risk disease ${ }^{8}$.

Among the various clinical and pathologic factors analyzed in a population-based study reported by the British Columbia Cancer Agency $(n=440)$, non-nodal presentation, defined as patients presenting with lymphocytosis and/or splenomegaly, was the single factor most strongly associated with prolonged time to treatment and excellent overall survival. In this study, median time to treatment was 35 months without a negative impact on overall survival in patients deemed suitable for initial observation. Other characteristics of the observed patients included good performance status, absence of B-symptoms, non-blastoid morphology, and Ki67 percentage of less than $30 \%$. There were no significant differences in the observed versus treatment groups, including in age at diagnosis, sex, leukocyte count, platelet count, stage, TP53 and SOX11 expression by IHC, and MIPI risk score ${ }^{5}$.

While there are no prospective data guiding observation in patients based on SOX11 or TP53 expression, these are additional variables that can be considered clinically to predict disease course. In the British Columbia study above, P53 positivity was defined as strong nuclear staining and SOX11 was positive if any cells stained positive. A second study by the European MCL Network sorted patients into groups based on percentage of P53-positive cells $(1-10 \%, 10-50 \%$, and over 50\%) and SOX11 cells $(0 \%, 1-10 \%$, and over $10 \%)$ by IHC IH $^{9}$ Inis study, the cohort with over 50\% TP53 expression had poorer prognosis, while SOX11 expression was not a reliable prognostic marker, possibly owing to an under-representation of patients with non-nodal disease. Another explanation is a difference in methods to determine SOX11 positivity, as Navarro et al. used a combination of reverse transcriptase polymerase chain reaction (RT-PCR) to measure SOX11 RNA, IHC to measure SOX11 protein, and gene expression profiling and observed an improved clinical outcome with low SOX11 expression. 
It is important to note that no patients in the above cohorts were observed with the pathologic blastoid variant of MCL, which continues to be a clinical challenge ${ }^{10}$. This group, which comprises less than $20 \%$ of total MCL diagnoses, features medium-sized lymphocytes with indistinct cytoplasm and dispersed chromatin compared with classical-type MCL with smaller lymphocytes and condensed chromatin. In a subgroup analysis of all modern trials, the patients with blastoid phenotype have inferior survival and remission rates. A further understanding of the disease process in these patients is greatly needed for the development of novel therapies. Thus, when deciding on initial observations, we consider all of the aforementioned disease features and balance this with the patient's preferences and other comorbidities. It should be remembered that many patients will not behave as their risk features predict, so close monitoring for progression of disease is necessary in all observed patients.

\section{Treatment strategies in fit patients}

\section{Induction chemotherapy}

Once the decision is made to proceed with treatment, the oncologist must determine whether or not the patient is fit for intensive therapy. Treatment broadly consists of two components: cytarabinecontaining induction chemotherapy followed by ASCT. Phase II trials in the past decade have consistently demonstrated the impressive activity of cytarabine in MCL, namely in the HyperCVAD and VcR-CVAD regimens ${ }^{1-13}$. Since that time, the MCL Younger trial conducted by the European MCL Network provided phase III data to support cytarabine as the key agent in MCL induction ${ }^{14}$. This trial included patients aged 65 years or younger with stage II-IV MCL randomized to six cycles of R-CHOP (non-cytarabine group) versus alternating R-CHOP and R-DHAP for six cycles (cytarabine group). Patients then proceeded to ASCT with myeloablative conditioning. Time to treatment failure in the cytarabine group was 9.1 years compared with 3.9 years in the non-cytarabine cohort, a benefit attributed to deeper molecular responses in patients receiving cytarabine. This benefit came at the expense of higher hematologic and gastrointestinal toxicities. The impressive results of the MCL Younger trial have redefined the standard treatment paradigm for fit patients with MCL but also raise a number of interesting questions going forward. Ongoing long-term follow-up of the trial will demonstrate whether cytarabine immunochemotherapy results in treatment cures in certain patients, although long-term follow-up of the Nordic trial suggests that this may still not be the case $\mathrm{e}^{15,16}$. Additionally, it is unclear how much benefit cytarabine immunochemotherapy provides for blastoid-variant MCL, a cohort that made up less than $10 \%$ of the population in the MCL Younger trial. Similarly, among the $5 \%$ of patients with a high combined MIPI and Ki-67 expression score treated in the European MCL Network Younger trial, median overall survival was approximately 2 years ${ }^{8}$. Each of these patient subsets still perform poorly, even with modern cytarabine-containing regimens and/or ASCT, suggesting that novel treatment strategies are needed for these groups.

The use of ASCT consolidation in first remission is supported by data published by the European and Nordic groups who noted significantly prolonged progression-free survival (PFS) with $\mathrm{ASCT}^{15}$, with the European group randomizing patients to interferon versus $\mathrm{ASCT}^{17}$. However, these data were attained before the widespread use of cytarabine induction regimens, maintenance rituximab in first remission, and the discovery of BTK inhibitors. Thus, randomized data confirming the efficacy of ASCT are greatly needed given the number of novel strategies recently developed in MCL. The European MCL Network phase III TRIANGLE study is currently randomizing patients to an induction regimen containing the BTK inhibitor ibrutinib while also assessing whether an ibrutinib-containing induction regimen with maintenance can replace ASCT. This will be the first phase III trial to incorporate a targeted molecular therapy into the MCL induction regimen and also the first randomized study to test the efficacy of ASCT in the cytarabine and rituximab era.

\section{Post-transplant maintenance and surveillance}

While most patients have no evidence of disease post-ASCT, the high relapse rate of MCL supports the concept of undetectable minimal residual disease (MRD) that precedes the development of a clinical relapse. This has been most rigorously studied by the Nordic MCL Group, who have measured MRD both pre- and post-ASCT by designing individualized RT-PCR primers to detect clonal $\mathrm{IgH}$ rearrangements on bone marrow and peripheral blood samples $^{18}$. Seroconversion to positive RT-PCR or a fivefold increase in RT-PCR MRD levels was defined as a molecular relapse (but not counted as a clinical relapse). Followed prospectively, PFS in MRD-negative patients was 142 months compared with 35 months in MRD-positive patients. This improvement in PFS also correlated with an impressive overall survival advantage. While certainly a proof of concept, there is currently no wide-scale approach for measuring MRD in large numbers of patients, and these methods will require validation across more institutions. The absence of such a universal approach has prompted the investigation of maintenance rituximab to produce more durable long-term remissions post-ASCT ${ }^{19}$. The Nordic group first showed that pre-emptive treatment with four doses of rituximab at first sign of molecular relapse led to a re-induction of molecular remission in over $90 \%$ of patients ${ }^{20}$. Prospective phase III data to support maintenance rituximab have become available with the recent published results of the multicenter LyMa trial conducted in France $^{21}$. Patients were randomized in a 1:1 ratio, irrespective of MRD status, to observation versus 3 years of maintenance rituximab after four cycles of R-DHAP induction followed by ASCT. PFS at 4 years was $79 \%$ in the rituximab group versus $61 \%$ with observation alone. Importantly, rituximab maintenance provided a statistically significant overall survival advantage and thus should be considered a standard of care post-ASCT. What remains unanswered, however, is whether consolidative ASCT provides any additional benefit in the rituximab maintenance era. A major advance towards this question is currently underway in a phase III ECOG trial that is randomizing patients without MRD to autologous transplant with maintenance rituximab to rituximab alone (Table 1). Additionally, investigation into the feasibility and efficacy of ibrutinib as an alternative for (or adjuct to) rituximab and as a replacement for ASCT will be addressed in the phase III TRIANGLE study and a phase II trial currently enrolling at our institution (Table 1).

It is important to analyze the results of the LyMa trial in the context of the MCL Younger trial. The LyMa trial produced 
Table 1. Current clinical trials in mantle cell lymphoma (MCL). Notable current clinical trials in MCL organized by clinical indication. Certain trials appear twice given their design to answer multiple clinical questions. ASCT, autologous stem cell transplant; BCL-2, B-cell lymphoma 2; BR, bendamustine-rituximab; BTK, Bruton's tyrosine kinase; CAR-T; chimeric antigen receptor T-cell; HDAC, histone deacetylase; R-Hyper-CVAD, rituximab plus fractionated cyclophosphamide, vincristine, doxorubicin, and dexamethasone plus methotrexate and cytarabine; MRD, minimal residual disease; PI3K, phosphoinositide 3-kinase; $\mathrm{R}^{2}$, lenalidomide plus rituximab; R-CHOP, rituximab, cyclophosphamide, doxorubicin, vincristine, and prednisolone; R-DHAP, rituximab, dexamethasone, cytarabine, and cisplatin; R-HAD, rituximab, high-dose cytarabine, and dexamethasone.

\begin{tabular}{|c|c|c|c|c|c|}
\hline $\begin{array}{l}\text { Category of } \\
\text { therapy }\end{array}$ & Study design or regimen & Target or drug class & $\begin{array}{l}\text { Clinical trials } \\
\text { identifier }\end{array}$ & Status & Phase \\
\hline \multirow[t]{2}{*}{ Fit induction } & $\begin{array}{l}\text { R-CHOP/R-DHAP + ASCT vs. } \\
\text { R-CHOP/R-DHAP + ibrutinib vs. } \\
\text { R-CHOP/R-DHAP + ibrutinib + ASCT }\end{array}$ & BTK & $\begin{array}{l}\text { NCT02858258 } \\
\text { (TRIANGLE) }\end{array}$ & Recruiting & Phase III \\
\hline & R-HyperCVAD + Ibrutinib & BTK & NCT02427620 & Recruiting & Phase II \\
\hline \multirow[t]{4}{*}{ Unfit induction } & $B R+$ ibrutinib & BTK & $\begin{array}{l}\text { NCT01776840 } \\
\text { (SHINE) }\end{array}$ & Active & Phase III \\
\hline & R-CHOP/R-HAD vs. R-CHOP & Cytarabine & NCT01865110 & Recruiting & Phase III \\
\hline & $\mathrm{BR}+$ acalabrutinib & BTK & NCT02972840 & Recruiting & Phase III \\
\hline & Bendamustine + obinutuzumab & Anti-CD20 & NCT03311126 & Recruiting & Phase II \\
\hline \multirow[t]{4}{*}{ Maintenance } & $\begin{array}{l}\text { Rituximab vs. ASCT + rituximab in } \\
\text { MRD-negative patients }\end{array}$ & Anti-CD20 & NCT03267433 & Recruiting & Phase III \\
\hline & $\begin{array}{l}\text { ASCT +/- ibrutinib maintenance vs } \\
\text { ibrutinib maintenance (no ASCT); } \\
\text { rituximab may be added to each arm }\end{array}$ & BTK & $\begin{array}{l}\text { NCT02858258 } \\
\text { (TRIANGLE) }\end{array}$ & Recruiting & Phase III \\
\hline & Ibrutinib without ASCT & BTK & NCT02242097 & Recruiting & Phase II \\
\hline & $\mathrm{R}^{2} \mathrm{vs}$. rituximab maintenance & Anti-CD20 + Imid & NCT01865110 & Recruiting & Phase III \\
\hline \multirow[t]{10}{*}{ Relapsed MCL } & $\begin{array}{l}\text { Obinutuzumab + GDC-0199 + } \\
\text { lbrutinib }\end{array}$ & Anti-CD20, BCL-2, BTK & NCT02558816 & Recruiting & Phase II \\
\hline & Obinutuzumab + Ibrutinib & Anti-CD20 + BTK & NCT02736617 & Recruiting & Phase II \\
\hline & KTE-C19 & CAR-T & $\begin{array}{l}\text { NCT02601313 } \\
\text { (ZUMA-2) }\end{array}$ & Recruiting & Phase II \\
\hline & JCAR017 & CAR-T & $\begin{array}{l}\text { NCT02631044 } \\
\text { (TRANSCEND) }\end{array}$ & Recruiting & Phase I \\
\hline & Ixazomib + Ibrutinib & Proteasome + BTK & NCT03323151 & Recruiting & Phase II \\
\hline & Bortezomib + Ibrutinib & Proteasome + BTK & NCT02356458 & Recruiting & Phase II \\
\hline & INCB050465 & $\mathrm{PI3K}$ & NCT03235544 & Recruiting & Phase II \\
\hline & Entospletinib & Syc & NCT01799889 & Active & Phase II \\
\hline & Vorinostat & HDAC & NCT00875056 & Recruiting & Phase II \\
\hline & Enzalutamide & Androgen & NCT02489123 & Recruiting & Phase II \\
\hline
\end{tabular}

impressive results with an anthracycline and alkylating-free induction regimen. Patients who failed to respond to four cycles of R-DHAP proceeded to salvage R-CHOP prior to transplant. This stepwise progression spared over $90 \%$ of the study participants from additional cytotoxic chemotherapy exposure and their associated long-term toxicities.

\section{Therapy strategies in unfit patients}

The treatment paradigm in MCL changes when patient preferences or comorbidities preclude intensive therapies including ASCT. In this scenario, clinical judgment should drive the safest and most-effective induction chemotherapy regimen. A phase III randomized trial established superiority of R-CHOP over fludarabine plus cyclophosphamide in unfit patients with a median age of 70 and confirmed the benefit of lifetime rituximab maintenance in responders ${ }^{22}$. Since this study, a number of regimens have shown marked improvement in clinical outcomes over R-CHOP (Table 2). MCL patients comprised approximately $15-20 \%$ of the total treated population in two recent phase III studies demonstrating non-inferiority of bendamustinerituximab (BR) to $\mathrm{R}-\mathrm{CHOP}^{23,24}$. BR demonstrated an improved safety profile and PFS that carried through into the MCL subgroup analysis. It should be noted that while these trials were designed for elderly patients with non-aggressive NHL, the median age 
Table 2. Regimens for mantle cell lymphoma (MCL). This table presents treatment regimens for MCL organized by clinical indication. BR, bendamustine-rituximab; CRR, complete response rate; $\mathrm{CrU}$, unconfirmed complete response rate; LBR, lenalidomide, bendamustine, and rituximab; ORR, overall response rate; $N R$, not reported; $R^{2}$, lenalidomide plus rituximab; R-BAC(500), rituximab, bendamustine, and cytarabine with low-dose cytarabine; R-CHOP, rituximab, cyclophosphamide, doxorubicin, vincristine, and prednisolone; R-DHAP, rituximab, dexamethasone, cytarabine, and cisplatin; R-Hyper-CVAD, rituximab plus fractionated cyclophosphamide, vincristine, doxorubicin, and dexamethasone; RiBVD, rituximab, bendamustine, bortezomib, and dexamethasone; VcR-CVAD, bortezomib, rituximab, hyperfractionated cyclophosphamide, vincristine, doxorubicin, and dexamethasone; VR-CAP, bortezomib, rituximab, cyclophosphamide, doxorubicin, and prednisone.

\begin{tabular}{|c|c|c|c|c|c|}
\hline Treatment category & Regimen & $\begin{array}{l}\text { Number of } \\
\text { patients }\end{array}$ & ORR & CRR (CrU) & Reference \\
\hline \multirow[t]{4}{*}{ Fit patients } & R-Hyper-CVAD & 97 & $97 \%$ & $77 \%(87 \%)$ & 12 \\
\hline & VcR-CVAD & 75 & $95 \%$ & $68 \%$ & 11 \\
\hline & R-DHAP $\times 4$ & 299 & $89 \%$ & $41 \%(77 \%)$ & 20 \\
\hline & R-DHAP/R-CHOP $\times 6$ & 248 & $94 \%$ & $55 \%(91 \%)$ & 13 \\
\hline \multirow[t]{6}{*}{ Unfit patients } & $\mathrm{BR}$ & 50 & $94 \%$ & $50 \%$ & 22 \\
\hline & RiBVD & 74 & $86 \%$ & NR $(74 \%)$ & 24 \\
\hline & LBR & 50 & $88 \%$ & $32 \%(64 \%)$ & 25 \\
\hline & $\mathrm{R}^{2}$ & 38 & $92 \%$ & $64 \%$ & 26 \\
\hline & VR-CAP & 229 & $92 \%$ & $53 \%$ & 27 \\
\hline & $\mathrm{R}-\mathrm{BAC}(500)$ & 57 & NR & $91 \%$ & 28 \\
\hline \multirow[t]{6}{*}{ Relapsed disease } & Bortezomib & 155 & $33 \%$ & $6 \%(8 \%)$ & 29 \\
\hline & Temsirolimus & 54 & $22 \%$ & $2 \%$ & 30 \\
\hline & Lenolidamide & 170 & $78 \%$ & $19 \%(11 \%)$ & 31 \\
\hline & Ibrutinib & 139 & $72 \%$ & $19 \%$ & 8 \\
\hline & Acalabrutinib & 124 & $81 \%$ & $40 \%$ & 32 \\
\hline & Ibrutinib + Venetoclax & 24 & $71 \%$ & $62 \%$ & 33 \\
\hline
\end{tabular}

difference compared with the MCL Younger study was a modest 5-10 years. Therefore, as is probably true in oncology in general, the decision of intensive treatment should be based more on performance status and goals of therapy than absolute age alone.

A number of studies have attempted to improve the efficacy of the BR backbone in elderly patients by including agents which have shown efficacy in relapsed disease. These include phase II data demonstrating the efficacy of adding bortezomib, dexamethasone, and lenalidomide (RiBVD) ${ }^{25}$, lenalidomide $(\mathrm{LBR})^{28}$, or cytarabine $(\mathrm{R}-\mathrm{BAC} 500)^{26}$. The results of the phase III SHINE study combining BR with ibrutinib should be available in the upcoming year. It is also possible to spare certain patients alkylating chemotherapy, as an $85 \%$ PFS was achieved with a 12-cycle regimen of lenalidomide plus rituximab $\left(\mathrm{R}^{2}\right)^{27}$. Improved PFS was observed in the phase III LYM-3002 study by substituting bortezomib for vincristine in the VR-CAP regimen in a patient population with a median age of $65^{29}$. Given these results, our preference has been to utilize these newer regimens with rituximab maintenance over traditional $\mathrm{R}-\mathrm{CHOP}$ alone in unfit patients, with options summarized in Table 2, tailored to patients based on tolerability, comorbid conditions, and performance status.
As mentioned above, based on the success of cytarabinecontaining induction regimens in younger fit patients, the Italian MCL group studied its addition to a BR backbone in elderly patients $(\mathrm{R}-\mathrm{BAC} 500)^{26}$. Rather than three doses at $2 \mathrm{~g} / \mathrm{m}^{2}$ in the MCL younger trial (D-HAP regimen), the investigators lowered the cytarabine dose to three doses at $500 \mathrm{mg} / \mathrm{m}^{2}$ per cycle. This produced an acceptable hematological toxicity profile that allowed $95 \%$ of patients to complete four cycles of therapy. PFS was approximately $75 \%$ at 3 years in a patient population with a median age of 71 , an impressive result given rituximab maintenance was not included in the protocol. These results warrant confirmation in a randomized setting and may prove to be the next major advance to sustainable remissions in the elderly population.

\section{Relapsed mantle cell lymphoma}

Relapsed MCL has historically been characterized by poor response rates and an overall survival of less than 3 years. However, the past decade has seen multiple agents approved with single agent efficacy in relapsed disease. First, the proteasome inhibitor bortezomib received FDA approval in MCL based upon phase II clinical data demonstrating a median PFS of approximately 6 months $^{30}$. A multicenter open-label phase III study demonstrated 
superiority of temsirolimus to investigator's choice therapy with a median PFS of 4.8 months, leading to its approval in Europe ${ }^{34}$. Third, the phase II EMERGE trial confirmed the activity of lenalidomide in patients with progression of disease on bortezomib, with an overall response rate (ORR) of $28 \%$ in a heavily pre-treated population and durable efficacy with long-term follow-up, leading to lenalidomide's approval in the US ${ }^{31,35}$. Subsequently, the SPRINT trial conducted by the European MCL Network randomized 254 patients to receive lenalidomide versus investigator's choice treatment and found a median PFS of 8.7 months in the lenalidomide group compared with 5.2 months in the control population ${ }^{36}$. In an international phase II trial in relapsed MCL patients treated with single-agent ibrutinib and included patients previously exposed to bortezomib ${ }^{32}$, a 17.5-month PFS survival was observed. Lastly, pre-existing atrial fibrillation and need for anticoagulation has limited the use of ibrutinib in certain patients and led to the development and approval of the selective BTK inhibitor acalabrutinib. Phase II data have shown a favorable safety profile and durable remissions with this agent, but its non-inferiority or superiority to ibrutinib has not been tested ${ }^{37}$. Nonetheless, this agent has also recently received FDA approval for relapsed/refractory MCL.

The impressive PFS of single-agent ibrutinib prompted a European phase III multicenter study comparing single-agent ibrutinib with temsirolimus ${ }^{33}$. Median PFS in patients with ibrutinib was 14.2 months compared with 6.2 months in the temsirolimus cohort, confirming prior phase II data. Importantly, ibrutinib was associated with fewer treatment-related adverse effects. While the difference in overall survival was not significant between the two groups, $23 \%$ of patients assigned to temsirolimus subsequently received ibrutinib at relapse, perhaps confounding the overall survival data. This study is the highest-quality evidence supporting ibrutinib as standard of care in patients with relapsed MCL.

Multiple efforts are now underway to combine the small molecule inhibitors with single agent activity in relapsed and refractory MCL (Table 1). Most recently, promising phase II data combining ibrutinib and the BCL-2 inhibitor venetoclax in 24 patients achieved a $42 \%$ complete response rate (CRR) compared with a 9\% CRR in historical controls ${ }^{38,39}$. The efficacy and safety of this combination will have to be confirmed in a larger cohort, but this is an early indication that synergism between single agents may be a fruitful strategy in this disease.

For patients who unfortunately fail to respond to the traditional and novel therapies, allogeneic stem cell transplant (allo-SCT) remains a salvage option for disease control ${ }^{40,41}$. It is difficult to know the exact benefit of allo-SCT given the lack of randomized data in a population with few alternative options. However, the German group produced 5-year PFS rates of $67 \%$ in this high-risk group with plateauing survival curves that suggest some of these patients may be cured. This benefit, not surprisingly, comes at the cost of a treatment-related mortality rate of approximately $25 \%$. As in all cases of allo-SCT, a referral to a high-volume transplant center is key for the best outcome.

\section{New insights into mantle cell lymphoma pathogenesis and future therapies}

Despite the promising single agent efficacy of ibrutinib, more options are badly needed for patients with relapsed disease given the 1-year overall survival rate of approximately $70 \%$ in the ibrutinib era ${ }^{33}$. Recent studies into mechanisms for ibrutinib resistance have identified the upregulation of NF- $\mathrm{\kappa B}$ signaling as an adaptive mechanism to bypass the antigen receptor B-cell signaling inhibited by ibrutinib ${ }^{42,43}$. The bromodomain family of proteins are transcriptional enhancers that are required for NF- $\mathrm{NB}$ signaling and thus are an attractive target in MCL. Bromodomain antagonists have been shown to work synergistically with ibrutinib in vitro to induce apoptosis in MCL cell lines ${ }^{44,45}$. Further studies are awaited to assess whether these agents can be safely used in vivo alone or with ibrutinib.

The recent approval of chimeric antigen receptor T-cell (CAR-T) therapy in large cell lymphoma has opened up a novel line of therapy for patients. Indeed, a phase II study of CAR-T therapy in relapsed MCL is currently underway with an identical CD19 antigen receptor (Table 1). As practitioners gain more experience with the administration of these products, there will be great interest in testing their efficacy both in a relapsed setting and as part of upfront therapy versus consolidative ASCT.

The male to female predominance of approximately 4:1 in MCL led a group of investigators to examine androgen receptor (AR) expression in MCL cell lines ${ }^{46}$. Interestingly, compared with non-MCL cell lines, MCL cells demonstrate increased AR gene expression and elevated PSA levels consistent with active AR signaling. AR blockade with enzalutamide, an anti-androgen currently FDA approved in prostate cancer, decreased MCL cell proliferation, prompting the opening of a phase II trial to clinically investigate this effect (Table 1).

Further investigation into the molecularly defined subtypes of MCL has raised the possibility that the treatment might be tailored based on these results. For example, can a non-nodal SOX11negative patient be managed without intensive chemotherapy induction or consolidative ASCT? Additional genetic abnormalities are still being discovered and will likely impact the risk stratification of patients and treatment strategies. For example, ataxia-telangiectasia mutated (ATM) is altered in approximately $50 \%$ of MCL cases. This protein functions as a sensor for DNA damage and, while overall it does not impact long-term survival, it may sensitize MCL cells to DNA-damaging therapy or ionizing radiation ${ }^{47}$. A recent shotgun sequencing approach identified $12 \%$ of patients with NOTCH1 mutations that correlated with sensitivity of MCL cells to NOTCH inhibition in vitro ${ }^{48}$. Given the poorer prognosis of these patients, exploring drugs that target this particular mutation is appealing. TP53 mutations portend a dismal prognosis in MCL, and analysis of the TP53 cohort from the Nordic MCL2 and MCL3 trials suggests that these patients do not benefit from cytarabine-containing induction chemotherapy or $\mathrm{ASCT}^{49}$. Enrichment of these patients in clinical trials using recently approved small molecule inhibitors is needed. 
Given the number of potential therapies on the horizon in MCL, continued patient enrollment in clinical trials is of the utmost importance. Patients who are fit and unfit for induction as well as patients with relapsed disease should be encouraged to participate, as previous MCL trials have been criticized for their bias for healthier patients ${ }^{50}$. This can not only confound non-randomized phase II efficacy data but also underestimate the side effect and toxicity data of newer regimens as they are applied to a more representative population.

\section{Conclusions}

The exciting developments in MCL over the past decade have begun to make substantial improvements in patient quality of life and overall survival. Ongoing long-term follow-up of the most recent clinical data will hopefully provide further evidence of durable remissions and acceptable long-term side effect profiles. We await new data incorporating our newest therapies, such as ibrutinib, with induction cytarabine chemotherapy regimens to possibly eliminate the need for upfront ASCT. The optimal duration of rituximab maintenance post-induction and whether ibrutinib maintenance is a safe and efficacious alternative to rituximab also remain unanswered. Despite these recent advances, our new therapies still fail in many patients. The continued development of targeted molecular signaling inhibitors based on the underlying biology of MCL is a therapeutic approach that will continue to yield fruitful results in this disease.

\section{Competing interests}

The authors declare that they have no competing interests.

\section{Grant information}

The author(s) declared that no grants were involved in supporting this work.
1. Salaverria I, Royo C, Carvajal-Cuenca A, et al.: CCND2 rearrangements are the most frequent genetic events in cyclin D1- mantle cell lymphoma. Blood. 2013 121(8): 1394-402.

PubMed Abstract | Publisher Full Text | Free Full Text

2. Mozos A, Royo C, Hartmann E, et al.: Sox11 expression is highly specific for mantle cell lymphoma and identifies the cyclin D1-negative subtype. Haematologica. 2009; 94(11): 1555-62. PubMed Abstract | Publisher Full Text | Free Full Text

3. Vegliante MC, Palomero J, Pérez-Galán $\mathrm{P}$, et al:: SoX11 regulates PAX5 expression and blocks terminal B-cell differentiation in aggressive mantle cell lymphoma. Blood. 2013; 121(12): 2175-85. PubMed Abstract | Publisher Full Text

4. Navarro A, Clot G, Royo C, et al.: Molecular subsets of mantle cell lymphoma defined by the IGHV mutational status and SOX11 expression have distinct biologic and clinical features. Cancer Res. 2012; 72(20): 5307-16. PubMed Abstract | Publisher Full Text | Free Full Text

5. F Abrisqueta P, Scott DW, Slack GW, et al: Observation as the initial management strategy in patients with mantle cell lymphoma. Ann Oncol. 2017; 28(10): 2489-95

PubMed Abstract | Publisher Full Text | F1000 Recommendation

6. $\quad \mathrm{F}$ Martin $\mathrm{P}$, Chadburn A, Christos $\mathrm{P}$, et al:: Outcome of deferred initial therapy in mantle-cell lymphoma. J Clin Oncol. 2009; 27(8): 1209-13. PubMed Abstract | Publisher Full Text | F1000 Recommendation

7. Hoster E, Klapper W, Hermine O, et al.: Confirmation of the mantle-cell lymphoma International Prognostic Index in randomized trials of the European Mantle-Cell Lymphoma Network. J Clin Oncol. 2014; 32(13): 1338-46. PubMed Abstract | Publisher Full Text

8. F Hoster E, Rosenwald A, Berger F, et al.: Prognostic Value of Ki-67 Index, Cytology, and Growth Pattern in Mantle-Cell Lymphoma: Results From Randomized Trials of the European Mantle Cell Lymphoma Network. J Clin Oncol. 2016; 34(12): 1386-94.

PubMed Abstract | Publisher Full Text | F1000 Recommendation

9. $\quad F$ Aukema SM, Hoster E, Rosenwald A, et al:: Expression of TP53 is associated with the outcome of MCL independent of MIPI and Ki-67 in trials of the European MCL Network. Blood. 2018; 131(4): 417-20. PubMed Abstract | Publisher Full Text | F1000 Recommendation

10. Bernard $M$, Gressin $R$, Lefrère $F$, et al:: Blastic variant of mantle cell lymphoma: A rare but highly aggressive subtype. Leukemia. 2001; 15(11): 1785-91. PubMed Abstract | Publisher Full Text

11. Chang JE, Carmichael LL, Kim K, et al.: VcR-CVAD Induction Chemotherapy Followed by Maintenance Rituximab Produces Durable Remissions in Mantle Cell Lymphoma: A Wisconsin Oncology Network Study. Clin Lymphoma Myeloma Leuk. 2018; 18(1): e61-e67. PubMed Abstract | Publisher Full Text | Free Full Text

12. Chang JE, Li H, Smith MR, et al.: Phase 2 study of VcR-CVAD with maintenance rituximab for untreated mantle cell lymphoma: an Eastern Cooperative Oncology Group study (E1405). Blood. 2014; 123(11): 1665-73. PubMed Abstract | Publisher Full Text | Free Full Text

13. Romaguera JE, Fayad L, Rodriguez MA, et al:: High rate of durable remissions after treatment of newly diagnosed aggressive mantle-cell lymphoma with rituximab plus hyper-CVAD alternating with rituximab plus high-dose methotrexate and cytarabine. J Clin Oncol. 2005; 23(28): 7013-23. PubMed Abstract | Publisher Full Text

14. F Hermine O, Hoster E, Walewski J, et al:: Addition of high-dose cytarabine to immunochemotherapy before autologous stem-cell transplantation in patients aged 65 years or younger with mantle cell lymphoma (MCL Younger): a randomised, open-label, phase 3 trial of the European Mantle Cell Lymphoma Network. Lancet. 2016; 388(10044): 565-75. PubMed Abstract | Publisher Full Text | F1000 Recommendation

15. Geisler $\mathrm{CH}$, Kolstad $\mathrm{A}$, Laurell $\mathrm{A}$, et al.: Long-term progression-free survival of mantle cell lymphoma after intensive front-line immunochemotherapy with in vivo-purged stem cell rescue: a nonrandomized phase 2 multicenter study by the Nordic Lymphoma Group. Blood. 2008; 112(7): 2687-93. PubMed Abstract | Publisher Full Text | Free Full Text

16. Geisler $\mathrm{CH}$, Kolstad A, Laurell A, et al: Nordic MCL2 trial update: six-year followup after intensive immunochemotherapy for untreated mantle cell lymphoma followed by BEAM or BEAC + autologous stem-cell support: still very long survival but late relapses do occur. Br J Haematol. 2012; 158(3): 355-62. PubMed Abstract | Publisher Full Text

17. Dreyling M, Lenz G, Hoster E, et al:: Early consolidation by myeloablative radiochemotherapy followed by autologous stem cell transplantation in first remission significantly prolongs progression-free survival in mantle-cell lymphoma: results of a prospective randomized trial of the European MCL Network. Blood. 2005; 105(7): 2677-84 PubMed Abstract | Publisher Full Text

18. F Kolstad A, Pedersen LB, Eskelund CW, et al:: Molecular Monitoring after Autologous Stem Cell Transplantation and Preemptive Rituximab Treatment of Molecular Relapse; Results from the Nordic Mantle Cell Lymphoma Studies (MCL2 and MCL3) with Median Follow-Up of 8.5 Years. Biol Blood Marrow Transplant. 2017; 23(3): 428-35.

PubMed Abstract | Publisher Full Text | F1000 Recommendation

19. Mei MG, Cao TM, Chen L, et al:: Long-Term Results of High-Dose Therapy and Autologous Stem Cell Transplantation for Mantle Cell Lymphoma: Effectiveness of Maintenance Rituximab. Biol Blood Marrow Transplant. 2017; 23(11): 1861-9. PubMed Abstract | Publisher Full Text | Free Full Text

20. Andersen NS, Pedersen LB, Laurell A, et al:: Pre-emptive treatment with rituximab of molecular relapse after autologous stem cell transplantation in mantle cell lymphoma. J Clin Oncol. 2009; 27(26): 4365-70. PubMed Abstract | Publisher Full Text

21. F Le Gouill S, Thieblemont $\mathrm{C}$, Oberic L, et al:: Rituximab after Autologous 
Stem-Cell Transplantation in Mantle-Cell Lymphoma. N Engl J Med. 2017; 377(13): 1250-60.

PubMed Abstract | Publisher Full Text | F1000 Recommendation

22. F Kluin-Nelemans HC, Hoster E, Hermine O, et al:: Treatment of older patients with mantle-cell lymphoma. N Engl J Med. 2012; 367(6): 520-31. PubMed Abstract | Publisher Full Text | F1000 Recommendation

23. F Flinn IW, van der Jagt R, Kahl BS, et al:: Randomized trial of bendamustinerituximab or R-CHOP/R-CVP in first-line treatment of indolent NHL or MCL: the BRIGHT study. Blood. 2014; 123(19): 2944-52.

PubMed Abstract | Publisher Full Text | Free Full Text | F1000 Recommendation

24. F Rummel MJ, Niederle N, Maschmeyer G, et al.: Bendamustine plus rituximab versus $\mathrm{CHOP}$ plus rituximab as first-line treatment for patients with indolent and mantle-cell lymphomas: An open-label, multicentre, randomised, phase 3 non-inferiority trial. Lancet. 2013; 381(9873): 1203-10.

PubMed Abstract | Publisher Full Text | F1000 Recommendation

25. Gressin R, Callanan M, Daguindau N, et al.: Frontline Therapy with the Ribvd Regimen Elicits High Clinical and Molecular Response Rates and Long PFS in Elderly Patients Mantle Cell Lymphoma (MCL); Final Results of a Prospective Phase II Trial By the Lysa Group. Blood. 2014; 124(21): 148.

Reference Source

26. F Visco C, Chiappella A, Nassi L, et al.: Rituximab, bendamustine, and lowdose cytarabine as induction therapy in elderly patients with mantle cell lymphoma: a multicentre, phase 2 trial from Fondazione Italiana Linfomi. Lancet Haematol. 2017; 4(1): e15-e23.

PubMed Abstract | Publisher Full Text | F1000 Recommendation

27. Ruan J, Martin P, Shah B, et al:: Lenalidomide plus Rituximab as Initial Treatment for Mantle-Cell Lymphoma. N Engl J Med. 2015; 373(19): 1835-44. PubMed Abstract | Publisher Full Text | Free Full Text

28. F Albertsson-Lindblad A, Kolstad A, Laurell A, et al:: Lenalidomidebendamustine-rituximab in patients older than 65 years with untreated mantle cell lymphoma. Blood. 2016; 128(14): 1814-20.

PubMed Abstract | Publisher Full Text | F1000 Recommendation

29. Robak T, Huang H, Jin J, et al:: Bortezomib-based therapy for newly diagnosed mantle-cell lymphoma. N Engl J Med. 2015; 372(10): 944-53.

PubMed Abstract | Publisher Full Tex

30. Fisher RI, Bernstein SH, Kahl BS, et al.: Multicenter phase II study of bortezomib in patients with relapsed or refractory mantle cell lymphoma. $J$ Clin Oncol. 2006; 24(30): 4867-74

PubMed Abstract | Publisher Full Text

31. Goy A, Kalayoglu Besisik S, Drach J, et al.: Longer-term follow-up and outcome by tumour cell proliferation rate (Ki-67) in patients with relapsed/refractory mantle cell lymphoma treated with lenalidomide on MCL-001(EMERGE) pivotal trial. Br J Haematol. 2015; 170(4): 496-503.

PubMed Abstract | Publisher Full Text | Free Full Text

32. $\mathrm{F}$ Wang $\mathrm{ML}$, Rule $\mathrm{S}$, Martin $\mathrm{P}$, et al.: Targeting BTK with ibrutinib in relapsed or refractory mantle-cell lymphoma. N Engl J Med. 2013; 369(6): 507-16. PubMed Abstract | Publisher Full Text | Free Full Text | F1000 Recommendation

33. F Dreyling $\mathrm{M}$, Jurczak $\mathrm{W}$, Jerkeman $\mathrm{M}$, et al:: Ibrutinib versus temsirolimus in patients with relapsed or refractory mantle-cell lymphoma: an international, randomised, open-label, phase 3 study. Lancet. 2016; 387(10020): 770-8. PubMed Abstract | Publisher Full Text | F1000 Recommendation

34. Hess G, Herbrecht R, Romaguera J, et al:: Phase III study to evaluate temsirolimus compared with investigator's choice therapy for the treatment of relapsed or refractory mantle cell lymphoma. J Clin Oncol. 2009; 27(23): 3822-9.

PubMed Abstract | Publisher Full Text

35. Goy A, Sinha R, Williams ME, et al:: Single-agent lenalidomide in patients with mantle-cell lymphoma who relapsed or progressed after or were refractory to bortezomib: phase II MCL-001 (EMERGE) study. J Clin Oncol. 2013; 31(29): 3688-95. PubMed Abstract | Publisher Full Text | Free Full Text

36. F Trněný M, Lamy $\mathrm{T}$, Walewski J, et al:: Lenalidomide versus investigator's choice in relapsed or refractory mantle cell lymphoma (MCL-002; SPRINT): A phase 2, randomised, multicentre trial. Lancet Oncol. 2016; 17(3): 319-31.

PubMed Abstract | Publisher Full Text | F1000 Recommendation

37. F Wang M, Rule S, Zinzani PL, et al.: Acalabrutinib in relapsed or refractory mantle cell lymphoma (ACE-LY-004): a single-arm, multicentre, phase 2 trial. Lancet. 2018; 391(10121): 659-67.

PubMed Abstract | Publisher Full Text | F1000 Recommendation

38. F Tam CS, Anderson MA, Pott C, et al: Ibrutinib plus Venetoclax for the Treatment of Mantle-Cell Lymphoma. N Engl J Med. 2018; 378(13): 1211-23. PubMed Abstract | Publisher Full Text | F1000 Recommendation

39. Davids MS, Roberts AW, Seymour JF, et al:: Phase I First-in-Human Study of Venetoclax in Patients With Relapsed or Refractory Non-Hodgkin Lymphoma. $J$ Clin Oncol. 2017; 35(8): 826-33. PubMed Abstract | Publisher Full Text | Free Full Text

40. Krüger WH, Hirt C, Basara N, et al.: Allogeneic stem cell transplantation for mantle cell lymphoma--final report from the prospective trials of the East German Study Group Haematology/Oncology (OSHO). Ann Hematol. 2014; 93(9): 1587-97.

PubMed Abstract | Publisher Full Text

41. Tessoulin $B$, Ceballos $P$, Chevallier $P$, et al:: Allogeneic stem cell transplantation for patients with mantle cell lymphoma who failed autologous stem cell transplantation: a national survey of the SFGM-TC. Bone Marrow Transplant. 2016; 51(9): 1184-90.

PubMed Abstract | Publisher Full Text

42. F Rahal R, Frick M, Romero R, et al.: Pharmacological and genomic profiling dentifies NF-кB-targeted treatment strategies for mantle cell lymphoma. $\mathrm{Na}$ Med. 2014; 20(1): 87-92.

PubMed Abstract | Publisher Full Text | F1000 Recommendation

43. F Saba NS, Liu D, Herman SE, et al.: Pathogenic role of B-cell receptor signaling and canonical NF-кB activation in mantle cell lymphoma. Blood. 2016; 128(1): 82-92.

PubMed Abstract | Publisher Full Text | Free Full Text | F1000 Recommendation

44. Sun B, Fiskus W, Qian Y, et al.: BET protein proteolysis targeting chimera (PROTAC) exerts potent lethal activity against mantle cell lymphoma cells. Leukemia 2018: 32(2): 343-52.

PubMed Abstract | Publisher Full Text

45. Sun B, Shah B, Fiskus W, et al:: Synergistic activity of BET protein antagonistbased combinations in mantle cell lymphoma cells sensitive or resistant to ibrutinib. Blood. 2015; 126(13): 1565-74.

PubMed Abstract | Publisher Full Text | Free Full Text

46. Mostaghel EA, Martin PS, Mongovin S, et al.: Androgen receptor expression in mantle cell lymphoma: Potential novel therapeutic implications. Exp Hematol. 2017; 49: 34-38.e2.

PubMed Abstract | Publisher Full Text | Free Full Text

47. F Ahmed M, Li L, Pinnix C, et al:: ATM mutation and radiosensitivity: An opportunity in the therapy of mantle cell lymphoma. Crit Rev Oncol Hematol. 2016; 107: 14-9.

PubMed Abstract | Publisher Full Text | F1000 Recommendation

48. Kridel $\mathrm{R}$, Meissner $\mathrm{B}$, Rogic $\mathrm{S}$, et al.: Whole transcriptome sequencing reveals recurrent NOTCH1 mutations in mantle cell lymphoma. Blood. 2012; 119(9): 1963-71

PubMed Abstract | Publisher Full Text

49. F Eskelund CW, Dahl C, Hansen JW, et al.: TP53 mutations identify younger mantle cell lymphoma patients who do not benefit from intensive chemoimmunotherapy. Blood. 2017; 130(17): 1903-10. PublMed Abstract | Publisher Full Text | F1000 Recommendation

50. Augustin A, Le Gouill S, Gressin R, et al:: Survival benefit of mantle cell lymphoma patients enrolled in clinical trials; a joint study from the LYSA group and French cancer registries. J Cancer Res Clin Oncol. 2018; 144(4): 629-35.

PubMed Abstract | Publisher Full Text 


\section{Open Peer Review}

\section{Current Peer Review Status:}

\section{Editorial Note on the Review Process}

Faculty Reviews are review articles written by the prestigious Members of Faculty Opinions. The articles are commissioned and peer reviewed before publication to ensure that the final, published version is comprehensive and accessible. The reviewers who approved the final version are listed with their names and affiliations.

\section{The reviewers who approved this article are:}

\section{Version 1}

\section{Andre H. Goy}

Lymphoma Division, John Theurer Cancer Center, Hackensack, New Jersey, USA

Competing Interests: No competing interests were disclosed.

\section{Jonathon B. Cohen}

Winship Cancer Institute, Emory University, Atlanta, Georgia, USA

Competing Interests: No competing interests were disclosed.

\section{Vincent Ribrag}

Chairman of DITEP multidisciplinary committee and Chief of Molecular therapeutics in hematological early drug development, Gustave Roussy Comprehensive Cancer Center, Villejuif, France

Competing Interests: No competing interests were disclosed.

The benefits of publishing with F1000Research:

- Your article is published within days, with no editorial bias

- You can publish traditional articles, null/negative results, case reports, data notes and more

- The peer review process is transparent and collaborative

- Your article is indexed in PubMed after passing peer review

- Dedicated customer support at every stage

For pre-submission enquiries, contact research@f1000.com 